\title{
Enduring Policy Ideals and Practices - Evidence from Bangabandhu's Speech at the United Nations and Bangladesh's Voting Records at the Assembly: 2001-2017
}

\author{
Dr. Mohammad Zahidul Islam Khan \\ Academic Visitor, University of Reading \\ (mohammadzahidul.islamkhan@ reading.ac.uk)
}

\begin{abstract}
Bangabandhu Sheikh Mujibur Rahman's historic speech at the 29th session of the United Nations General Assembly (UNGA) was the first 'strategic communication' by the father of the nation at the Assembly following Bangladesh's admission to the United Nations. Apart from the well-known and much-to-be-proud of fact that the speech was delivered in Bangla, the content of this speech stands out as a key document, begging to be studied from an international relations perspective and the enduring ideals it enunciates and has been in practice by Bangladesh. This paper seeks to answer: to what extent has Bangladesh remain seized supporting the enduring ideals on key global issues enunciated by Bangabandhu in his speech at the United Nations? Accordingly, the paper carries out a (i) content analysis to identify the enduring ideals (ii) comparison of Bangladesh's positions on the 1,284 UNGA resolutions that were put to vote between 2001-2017 to assess country's support to those ideals. The paper finds that, except for the politically sensitive country-specific human rights resolutions, Bangladesh has consistently remained seized in supporting Bangabandhu's ideals in all thematic categories (between 92-100\% 'yes'votes). It demonstrates that Bangabandhu's emphasis on the primacy of the United Nations to build a peaceful and just world, non-alignment, peaceful co-existence, economic emancipation and global solidarity has become much more relevant in the Covid-19 era and the current geopolitical context of South Asia. The paper opens new avenues to use a novel methodology to conduct evidence-based research on the policy ideals and its practices.
\end{abstract}

Key words: Bangabandhu, United Nations General Assembly, voting records, policy and practice.

\section{Introduction}

On 25 September 1974, Bangabandhu ${ }^{1}$ Sheikh Mujibur Rahman made a historic speech at the 29th session of the United Nations General Assembly (UNGA) (A/PV.2243, 25 September 1974 p.159). This was his first 'strategic communication' at the Assembly following the newly born country's admission to the United Nations. Apart from the well-known and much-to-be-proud of fact that the speech was delivered in his mother tongue Bangla, the content of this speech stands out as a key document, begging to be studied and analysed from an international relations (IR) perspective and the enduring ideals it contained. The speech, hailed as the "Magna Carta" of Bangladesh's multilateral diplomatic principles, stands on the pillars of international peace and security based upon justice and economic emancipation (BSS, 2020). The chequered historical context and the importance attached to this widely quoted document demand a systematic and evidence-based comparative analysis of the ideals outlined by Bangabandhu with Bangladesh's practice of supporting global agendas. Thus, this paper seeks to answer: to what extent has Bangladesh remained seized in supporting the enduring ideals

\footnotetext{
1 'Bangabandhu (friend of Bengal)', is an honorific attested to him by the people of Bangladesh (Khan, 2020). The President of the 2243rd Plenary Meeting also invited him to address at the UNGA, as 'His Excellency Bangabandhu Sheikh Mujibur Rahman', attesting the universal recognition the honorific.
} 
on key global issues enunciated by Bangabandhu in his speech at the United Nations in 1974? Answering this question entails (i) content analysis to identify the key global issues and the enduring ideals outlined by Bangabandhu (ii) employing a benchmark to assess Bangladesh's support to those ideals at the United Nations. The primary evidence to answer the research question is from Bangabandhu's speech and Bangladesh's voting records on 1,284 UNGA resolutions that were put to vote between 2001-2017.

The paper fills the void in extant literature by offering a systemic and evidence-based analysis, contrasting the practice of descriptive and impressionistic account of this historic speech (Ahmed, 2019, 2020). The paper is organized as follows. First, a brief context of Bangladesh's birth and entry to the United Nations, highlighting the diplomatic wrangling in the Security Council regarding country's membership bid followed by the global and domestic situation, is discussed. It helps us to better connect and comprehend the speech. Second, the content of the speech (the official record in English) is analysed using an inductive method, to identify the policy guidance on key global issues and norms. It helps us to establish where Bangabandhu wanted the country to stand, supporting and advancing which global agendas. Subsequently, Bangladesh's adherence of these ideals, such as, international peace and justice, human rights (HR), disarmament, nuclear non-proliferation, economic emancipation, regional cooperation and so on, is traced by taking the country's voting records on 1,284 UNGA resolutions. The later discussion is preceded by outlining the data sources and methodology and a brief discussion on the nature of UNGA voting records to justify its usefulness and relevance as benchmark in this context.

\section{Bangladesh's entry to the United Nations}

The birth of Bangladesh in 1971 is the only example of forcibly creating a new state propelled by ethniclinguistic movement in the Cold War era. From a Cold War perspective, the United States viewed that a unified Pakistan would better serve the developing Sino-US relationship to contain the Soviet Union. Others Western states did not want to endorse the Indian intervention in Bangladesh for fear that it could incite similar situations in many other countries (Baxter, 1997. pp. 145-148; Blair, 2001; Jahan, 2001; US State Department 2006). Amidst a juxtaposed position of the two superpowers, two successive Soviet vetoes at the Security Council facilitated Bangladesh's birth by giving the precious time required for a swift military offensive by the Indians. However, Bangladesh's membership in the United Nations was not a straightforward issue. The country applied for the membership in August 1972. By the end of 1972, all global political powerhouses (except Pakistan, Saudi Arabia, and China) and several international organisations had extended the courtesy of official recognition to Bangladesh (Zarif 2020); yet the Security Council did not recommend Bangladesh's membership until 1974. This was the only exception in the Council's history of processing membership applications between 1972-74. The Indian representative at the Council presented a tabulated account of the time taken by the Committee to recommend the membership applications made by other countries, stressing that "since the thaw in the 
cold war, there has been no delay whatsoever in disposing of any application for membership" (S/PV1660, 25 August 1972, p. 4; UNSC 1974, pp.76-77). The lengthy discussions led to a vote on the "attitude" of members towards Bangladesh's membership bid and culminated in tabling two additional draft resolutions alongside the "three-Power draft resolution" tabled by the Soviet Union, United Kingdom, India and Yugoslavia for Bangladesh's immediate entry to the United Nations (see table 1) (S/10774, 23 August 1972, p.93).

China (on Pakistan's behest) suggested to 'postponed' Bangladesh's membership. Citing the Council resolution 307 (1971), Assembly resolution 3793 (XXVI), and the Charter, China tabled a draft resolution to defer Bangladesh's membership bid until the withdrawal of the Indian troops from Bangladesh and the release and repatriation of the prisoners of war. The Chinese representative also stated that Bangladesh's membership bid "runs entirely counter to the principles of the Charter"' (S/PV1660, 25 August 1972, p.8). In a letter to the Secretary-General, the permanent representative of India repeated the Indian Foreign Minister's assurance that the "Indian troops will not be in Bangladesh 'a day longer than necessary"' (S/10501, 11 January 1972, p.1). Although the Chinese draft resolution failed to obtain the required vote, China's veto against three-Power draft resolution (S/1 0771) resulted in deferring Bangladesh's entry to the United Nation. Interestingly, this was the first veto by China in the Security Council (Alden, 1972). In 1974, Bangladesh applied for 'renewed consideration' of her membership. The $1776^{\text {th }}$ Meeting of the Security Council recommended Bangladesh's application and the country became the $136^{\text {th }}$ member of the United Nation on 17 Sep 1974 - paving the way for Bangabandhu's historic speech at the Assembly later in the same month (S/11316, 7 Jun 1974; S/PV. 1776, 10 Jun 1974; A/PV.2233, 17 Sep 1974).

Table 1. Security Council voting record on the question of Bangladesh's admission to the UN in 1972.

\begin{tabular}{|c|c|c|c|c|}
\hline Draft Resolution & In favour & Against & Abstention & Outcome \\
\hline \multicolumn{5}{|c|}{$1660^{\text {th }}$ Meeting of the Security Council on 25 August 1972} \\
\hline $\begin{array}{l}\text { S/1 } 0768 \text { \& Corr. } 1 \\
\text { (China) for } \\
\text { postponement }\end{array}$ & $\begin{array}{l}\text { China, Guinea, } \\
\text { Sudan }\end{array}$ & $\begin{array}{l}\text { India, } \\
\text { USSR, } \\
\text { Yugoslavia }\end{array}$ & $\begin{array}{l}\text { Argentina, Belgium, } \\
\text { France, Italy, Japan, } \\
\text { Panama, Somalia, } \\
\text { UK, U.S.A. }\end{array}$ & $\begin{array}{l}\text { Not adopted. } \\
\text { (failed to obtain } \\
\text { nine affirmative } \\
\text { votes). }\end{array}$ \\
\hline $\begin{array}{l}\text { S/10775 (Guinea, } \\
\text { Somalia \& Sudan) } \\
\text { for amendment }\end{array}$ & $\begin{array}{l}\text { Guinea, Somalia, } \\
\text { Sudan, U.S.A. }\end{array}$ & $\begin{array}{l}\text { India, } \\
\text { USSR, UK, } \\
\text { Yugoslavia }\end{array}$ & $\begin{array}{l}\text { Argentina, Belgium, } \\
\text { China, France, Italy, } \\
\text { Japan, Panama. }\end{array}$ & $\begin{array}{l}\text { Not adopted. } \\
\text { (failed to obtain } \\
\text { nine affirmative } \\
\text { votes). }\end{array}$ \\
\hline $\begin{array}{l}\text { S/10771 (India, } \\
\text { USSR, UK, } \\
\text { Yugoslavia) } \\
\text { for immediate } \\
\text { membership }\end{array}$ & $\begin{array}{l}\text { Argentina, } \\
\text { Belgium, France, } \\
\text { India, Italy, } \\
\text { Japan, Panama, } \\
\text { USSR, UK, U.S.A. } \\
\text { Yugoslavia }\end{array}$ & China & $\begin{array}{l}\text { Guinea, } \\
\text { Sudan. }\end{array}$ & $\begin{array}{l}\text { Not adopted, } \\
\text { (negative vote } \\
\text { being that of a } \\
\text { permanent } \\
\text { member). }\end{array}$ \\
\hline
\end{tabular}

Source: Security Council, Official Record, S/PV-1660, 25 August 1972, pp. 7-10 
From a global perspective, the United States and China the two P-5 members, insofar as their governments were concerned, had overtly opposed Bangladesh's war of liberation. The post-World War II bipolar word system was a significant determinant of member state's behaviour and political proximity in the global forum. The politics of the Cold War had a distinctive impact in South Asia. China viewed that the "Soviet socialist-imperialism" was playing the "most insidious role in South Asia" to further "control India and Bangladesh" and increase its "sphere of influence"' in the Indian Ocean region China viewed the Indo-Soviet treaty of peace, friendship and co-operation signed in August 1971 as an "aggressive military alliance", that had stripped off India's "cloak of nonalliance"'(S/PV. 1660, 25 Aug 1972, p.9).

Amidst the constant flux of the bipolar world, the non-aligned movement portended a change in the United Nation's emphasis and approach to the world issues. The expansion of the non-aligned presence in the Assembly allowed space for the small states to operate as an active, independent agent, perhaps foreshadowing the displacement of balance-of-power politics by the Council and to cast off the role thrusted upon them as a 'pawn' of the two Super Powers (Stojanovic, 1981, pp.443-450).

The fight for self-determination was ongoing in many parts of the world, most notably in the Middle East and Africa. The period also witnessed the recurrence of global economic crises, triggered by the oil crisis and high inflations, culminating in the skyrocketing prices of food materials and manufactured goods. The natural disasters and famine had exacerbated the plight of millions of people in many countries including Bangladesh. The war-ravaged Bangladesh was faced with the worst famine in decades that begun in March 1974 and ended in December of the same year and massive flooding along the Brahmaputra river resulting in high mortality.

In sum, the events leading to Bangabandhu's speech at the Assembly in 1974 was quite chequered. The geopolitical context implied that the country's first 'strategic communication' in the United Nations platform should be pragmatic, measured and at the same time bold against extant global injustice, discrimination and inequality. It needed to set out an inclusive and enduring diplomatic principles for the newly independent country that would facilitate translating the growing recognition of Bangladesh into pledged for material assistance by the global community to rebuild the country. As a pragmatists and astute statesman, Bangabandhu skilfully balanced all these aspects in his speech. His enduring policy guidance for charting Bangladesh's engagements in the international arena is removed from the pretences and duplicity. It reflects his profound political acumen and wisdom to place the newly independent country as worthy equal amidst the power dynamics of a bipolar world system. Indeed, the speech stands out as the 'Magna Carta' of Bangladesh's multilateral diplomatic principles (Ahsan, 2020; The Business Standard, 2020). 


\section{Data and Methodology.}

The mainstay of the data used in this paper is from the official records of relevant Security Council and General Assembly meetings, statements, speeches, voting records and resolutions. The data is retrieved from the United Nations based websites, such as, the Dag Hammarskjold Library and United Nations Digital library. Chapter VII of the Repertoire of the Practice of the Security Council contains the deliberations on and references to the question of membership. The voting record on resolutions is obtained from The Index to Proceedings of the General Assembly, published each year by UN, Department of Public Information (UN DPI). The Index also provides the list of resolutions adopted by recorded or roll-call vote at the Assembly. The vote by each member state is recorded in the textual form such as Y (for 'yes'), N (for 'no'), A (for abstention) and 'blank' indicating absence. Bangladesh's voting data from 1975 is available. However, this paper uses Bangladesh's voting record from the fiftysixth session through the seventy-second session (2001-2017). This period is large enough to include preferences on wide-ranging resolutions made by two major political parties in Bangladesh who were in power during this period.

As mentioned before, the research question entails a qualitative content analysis followed by employing a benchmark to compare the policy ideals with the practices. An inductive method is used to analyse the content of the speech, focussing on the language intensely and similarity to classify the texts into an efficient number of thematic categories that represent similar ideas and meanings (Hsieh \& Shannon, 2005, p. 1278; Smith, 2000). Subsequently, the data on Bangladesh's voting preference on UNGA Resolutions (2001-2017) is used to compare the country's support to the specific ideals and thematic issues as derived by the inductive method. The use of the UNGA voting records as a benchmark to compare the ideals begs justification. While a detail discussion on the relevance and suitability of the UNGA voting records is beyond the scope of this paper and can be found elsewhere (Khan, 2020), a brief mention of its nature could be useful.

\section{The nature of the UNGA voting record}

The UNGA voting record is a product of the epistemic community - defined as "principal channel by which consensual knowledge about causal understandings is applied to international policy coordination and by which states may learn through processes of international cooperation" (Hass, 2011, p.2). A majority vote on a resolution reflects a consensus on global norms at the Assembly. Nevertheless, the resolutions are also non-binding, hence regarded as 'inconsequential' compared to the resolutions adopted in the Security Council. The voting preferences reflect member states' choices on a global issue, at a point of time, on which the member state may or may not take actions. Most of the resolutions adopted at the UNGA are without a vote. Many that are put to vote are also routine and recurring in nature. The voting data of the 1,284 resolutions, used in this paper were adopted in 1,873 plenary meetings between 2001-2017 (figure 1). The range of issues discussed at the plenary meetings, 
and the fact that the voting is a formal expression of member states' opinion, makes the data meaningful, and the platform, a key source for global policy innovation, diffusion and norm socialisation, albeit in a non-binding manner.

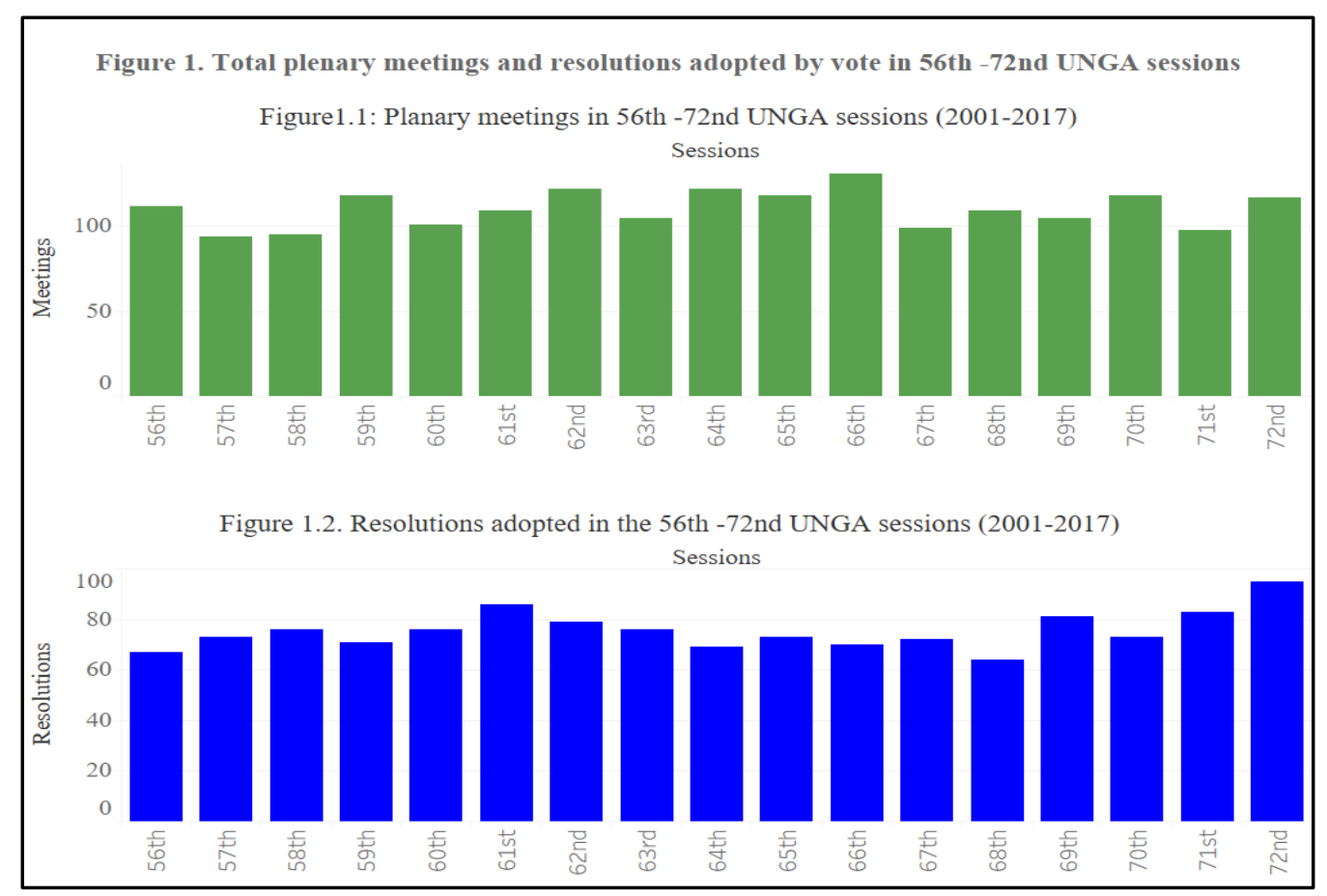

Source. Author's compilation from United Nations Department of Public Information (2001, 2002, 2003, 2004, 2005, 2006, 2007, 2008, 2009, 2010, 2011, 2012, 2013, 2014, 2015, 2016, 2017).

The Assembly is the hub for the proliferation and advancement of global norms on human rights, nuclear non-proliferation, disarmament, decolonisation, democracy and developmental issues. Figure 2 depicts the broad categories and the subsets of the thematic issues of the 1,284 resolutions. Researchers have used the UNGA voting data to investigate dynamic state preferences, systemic polarity in the international system, foreign aid effectiveness, alliance building, probability of conflicts, 'third world' solidarity and so on (Bailey, Strezhnev, \& Voeten 2017; Alesina \& Dollar,2000; de Mesquita, 1975; Dreher, Nunnenkamp \& Thiele, 2008; Khan, 2020; Pevehouse, 2004). The salience attached to different agendas and the member states' position on those issues, make the voting records a useful prism reflecting the mind of a state. Thus, Bangladesh's voting records could be a useful prism to investigate the extant at which Bangladesh remained seized in supporting the ideals on key global issues enunciated by Bangabandhu in his speech at the United Nations. 
Figure 2: Thematic categories of UNGA Resolutions: 2001-2017 (N=1284)

Figure 2.1: Broad thematic categories

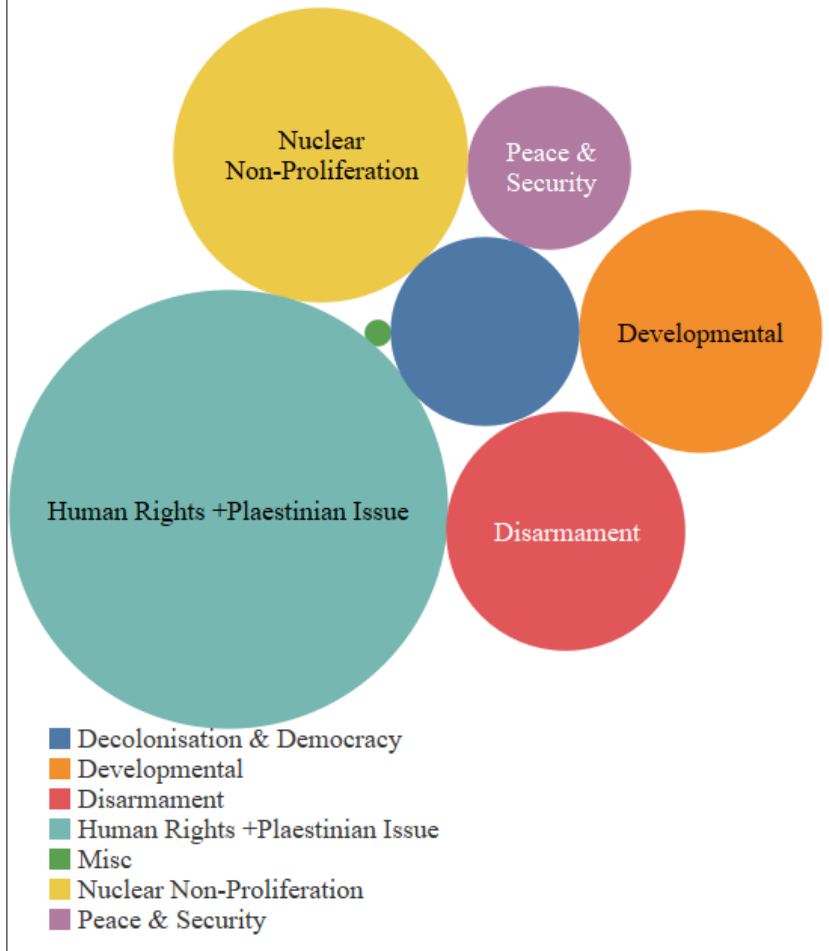

Figure 2.2: Subsets of thematic categories Subsets

Disarmament-Advancement $\mid 11$

Peace \& Security-Law of Sea 18

Peace \& Security-Advancement 20

Democracy-Advancement 24

Disarmament-Outer Space 27

Developmental-Budget \& Finan.. 28

Non-Proliferation-Missiles 28

Peace \& Security - Country Spe.. 37

Developmental-Economic \& En.. $\quad 66$

Developmental-Advancement 71

HR-Country-Specific 72

Nuclear Weapon Free World/Zo.. 76

Decolonisation $\square 77$

Disarmament-General \& Compl.. 122

Nuclear Non-Proliferation- Adv.. 140

HR-Advancement 203

HR-Palestinian Issue 252

$0 \quad 100 \quad 200 \quad 300$

Resolutions

Source. Author's compilation from United Nations Department of Public Information (2001, 2002, 2003, 2004, 2005, 2006, 2007, 2008, 2009, 2010, 2011, 2012, 2013, 2014, 2015, 2016, 2017).

\section{Thematic issues of Bangabandhu's speech}

The speech contains overlapping themes, articulated in 95 sentences, under 23 paragraphs. A subjective interpretation of the text (excluding the pleasantries) through a systematic process of classification and quantification of similar themes results in identifying six key thematic issues dominating the speech (see figure 3). The views on these issues help us to draw inference about where he wanted Bangladesh to stand, supporting which agendas and for what purpose and subsequently compare that with country's voting records at the UNGA - discussed next. 


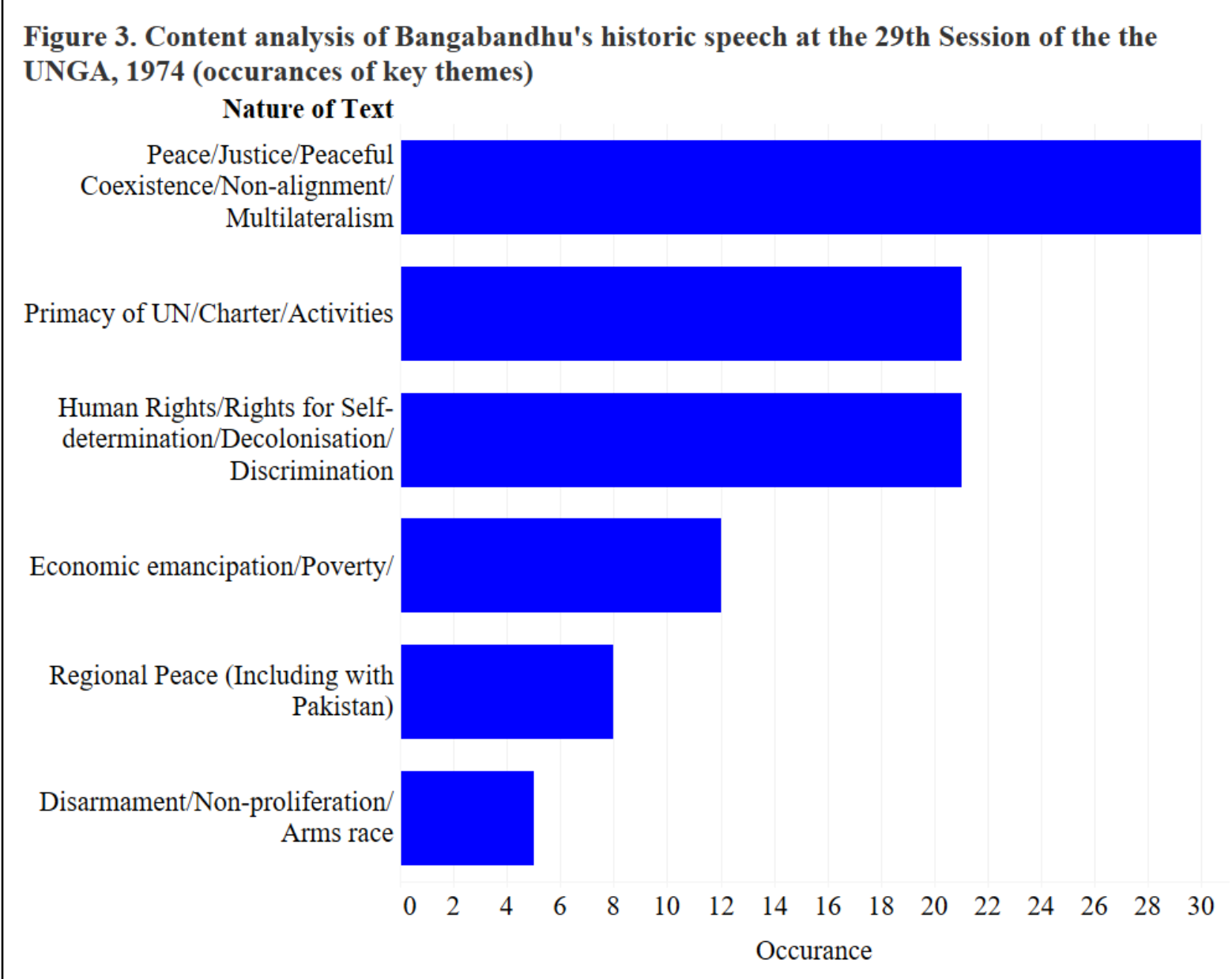

Source: Author's compilation from Official Document, A/PV.2243, 25 September 1974, pp. 159-161.

5.1 Primacy of the United Nations. Bangabandhu viewed the United Nations as a noble platform through which the "aspiration of all men for peace and justice will be realized." Described the United Nations as "man's hope for the future", he stated that the "noble ideals enshrined in the Charter of the United Nations are the very ideals for which millions of our [Bengali] people have made the supreme sacrifice"' (italics added). By drawing such parallel between the Charter and the sacrifice of the Bengali people, he essentially highlighted the universal legitimacy of Bangladesh's Liberation War. Attesting the United Nation's contributions in the human progress Bangabandhu acknowledged that, "there are few countries in the world that have a better realization than Bangladesh of the concrete achievements and potential for good of the Organization [i.e. UN]." Thus, it is not surprising to see that Bangladesh's Constitution (Art 25) states, "the State shall base its international relations on the principles of respect for national sovereignty and equality, non-interference in the internal affairs of other countries, peaceful settlement of international disputes, and respect for international law and the principles enunciated in the United Nations Charter...' In sum, the speech attests Bangabandhu's staunch support for the United Nations and its Charter. But how strongly has Bangladesh demonstrated her support towards the United Nations in recent years? 
Bangladesh's practice of supporting or opposing the UNGA resolutions can provide a practical insight in this regard. Figure 4 shows the session wise record of the Y/N/A votes by Bangladesh on the 1,270 resolutions where Bangladesh was 'present and voting' during this period. Overall, Bangladesh agreed to 92 per cent of the resolutions, disagreed to only 3 per cent and abstained from voting in 5 per cent resolutions. The session-wise voting record also demonstrates Bangladesh's high degree of support and confidence on the United Nations, attesting the fact that Bangladesh has continued to view the platform as "man's hope for the future", envisioned by Bangabandhu.

Figure 4. UNGA voting record of Bangladesh:2001-2017

( $\%$ of 'Y/N/A ' votes in each session, $n=1,270^{*}$ )

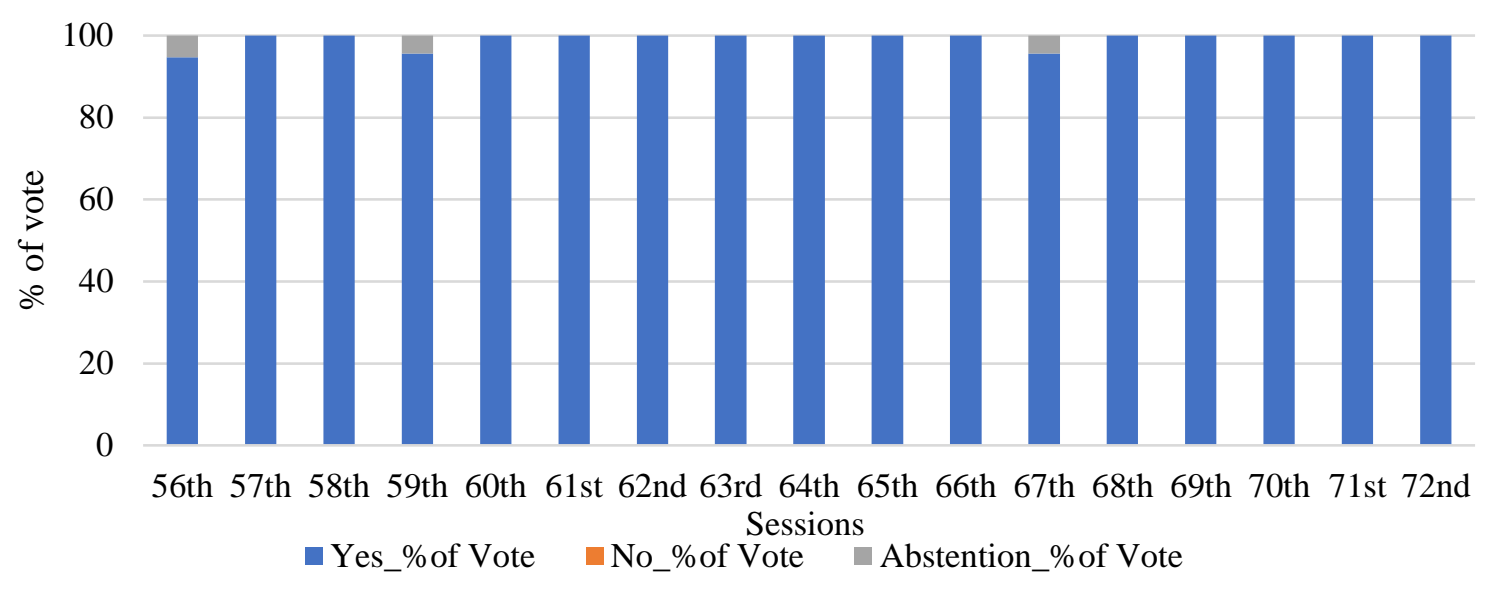

Source: Author's compilation from United Nations Department of Public Information (2001, 2002, 2003, 2004, 2005, 2006, 2007, 2008, 2009, 2010, 2011, 2012, 2013, 2014, 2015, 2016, 2017).

Note: * Data includes resolutions where Bangladesh was present and voting.

5.2 Nuclear non-proliferation and disarmament. Bangabandhu emphatically stated the danger of arms race and nuclear weapons to mankind, calling for their total elimination. Warning that the world is " "haunted by the fear of total destruction, threatened by nuclear war" he called upon the world leaders to build a "future free from the threat of nuclear war." On disarmament issues, he called for taking "urgent measures to control the present arms race" to stop the "massive resources currently being wasted on armaments." To him, the enemy of the mankind was "mass starvation", "unemployment" and the "wretchedness of deepening poverty." Instead of spending money in the arms race, Bangabandhu advocated for sharing the resources and technology on a global scale so that "men everywhere can begin to enjoy the minimal conditions of a decent life" and realise the common good of mankind.

Bangladesh's support to these ideals can be traced from her voting record on the disarmament \& nuclear non-proliferation related resolutions - most of which were recurring in nature. Figure 5 depicts Bangladesh's voting record on the 395 such resolutions that were put to vote between 2001-17. These resolutions call for 'achieving the universality of the nuclear Non-proliferation Treaty (NPT), devising 
'effectively verifiable treaty banning the production of fissile material for nuclear weapons or other nuclear explosives,' design disarmament and non-proliferation education and training program to promote a culture of non-violence and peace. The evidence suggests that the country has consistently supported all such resolutions with three abstentions but no opposition. Bangladesh changed her position from 'abstaining' to 'supporting' the resolution on The Hague code of conduct against ballistic missile proliferation and advancing multilateral nuclear disarmament negotiations. The other abstention (in 2001) vote on 'general and complete disarmament' relates to only one Section (24A), out of twenty four, of the resolution $(\mathrm{A} / \mathrm{RES} / 56 / 24 \mathrm{~A}-\mathrm{V})$. Overall, the voting record is indicative of Bangladesh's strong adherence to the ideals set out by Bangabandhu.

Figure 5. Bangladesh's voting record in disarmament \& nuclear nonproliferation issues ( $\%$ of ' $\mathrm{Y} / \mathrm{N} / \mathrm{A}^{\prime}$ ' votes/session, $\left.\mathrm{n}=395^{*}\right)$

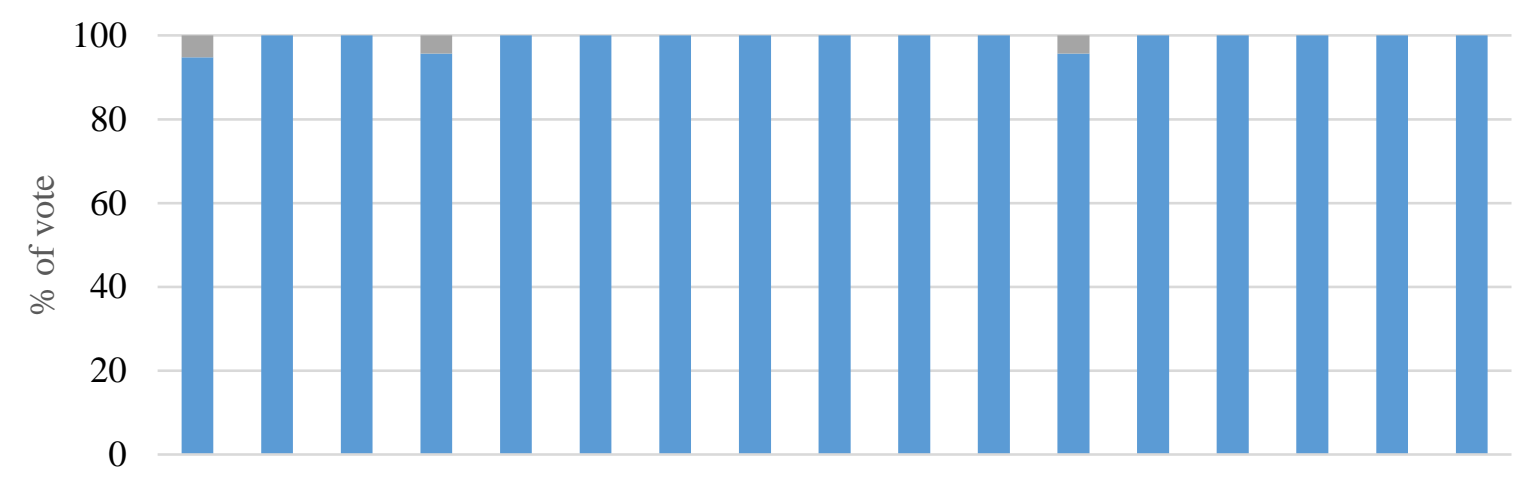

56th 57th 58th 59th 60th 61st 62nd 63rd 64th 65th 66th 67th 68th 69th 70th 71st 72nd Sessions

Yes_\%of Vote $\quad$ No_\%of Vote $\quad$ Abstention_\%of Vote

Source: Author's compilation from United Nations Department of Public Information (2001, 2002, 2003, 2004, 2005, 2006, 2007, 2008, 2009, 2010, 2011, 2012, 2013, 2014, 2015, 2016, 2017).

Note: * Data includes resolutions where Bangladesh was present and voting.

5.3 Economic \& developmental issues. Bangabandhu envisioned a "just international economic order." In his speech, he talked about ensuring the most basic economic right for all - " the right to a standard of living adequate for the health and well-being of himself and his family" and viewed this as a universal responsibility. He repeatedly emphasised the urgent need for the economic emancipation of the developing world. Being mindful of the fact that the world was facing great economic upheavals, he suggested the need for "marshalling the forces of reason, establishing a framework of international co-operation, ensuring the sovereignty of each State over its natural resources.' To tackle the recurring natural disaster, Bangabandhu suggested "an institutional arrangement by which the international community can move effectively to meet and prevent such calamities.' He suggested to strengthen the newly established Office of the United Nations Disaster Relief Coordinator (UNDRO), realised later in 1992 by the United Nations. 
Figure 6. Bangladesh's voting record in economic \& developmenal issues $\left(\%\right.$ of ' $\mathrm{Y} / \mathrm{N} / \mathrm{A}^{\prime}$ ' votes, $\left.\mathrm{n}=164 *\right)$

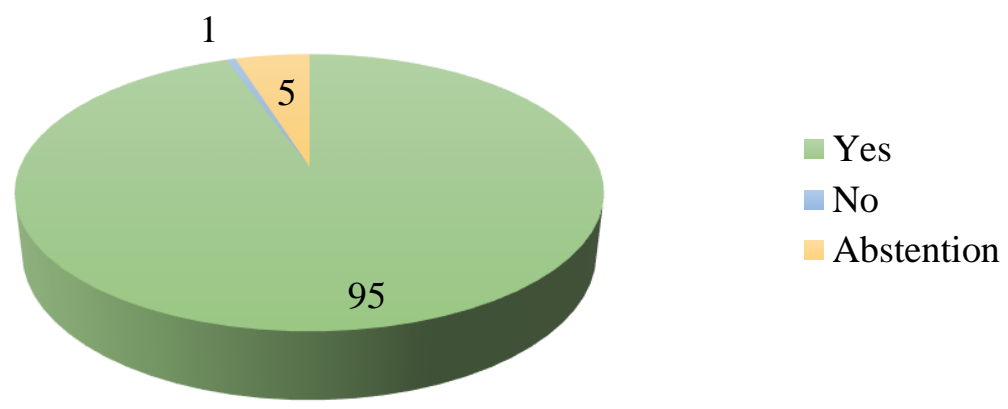

Source: Author's compilation from United Nations Department of Public Information (2001, 2002, 2003, 2004, 2005, 2006, 2007, 2008, 2009, 2010, 2011, 2012, 2013, 2014, 2015, 2016, 2017).

Note: * Data includes resolutions where Bangladesh was present and voting.

He also did not hesitate to warn the world leaders that the failure to establish a just economic order would leave the world with an unparalleled legacy "of such human misery having to be endured by so many side by side with such unprecedented levels of affluence and prosperity enjoyed by so few." His clarion call for human solidarity and brotherhood to regenerate the feeling of and an acknowledgement of interdependence transcends his time and has become much more relevant in the Covid-19 era. The voting records (figure 6) reflect that, Bangladesh has consistently supported almost all resolutions on developmental and economic emancipation and advancement (95\% yes votes). Bangladesh's position changed from opposing/abstaining (in 2012 \& 2014) to supporting the resolution on "entrepreneurship for development" in 2016. The country has also changed her initial position from supporting the resolution on agricultural technology for development (in 2007) to 'abstaining' in its subsequent occurrences.

5.4 Human rights and self-determination. The speech registers Bangabandhu's strong endorsement for the universal human rights and the rights for self-determination. As the iconic leader of a nation that has just come out of the shackle of oppression after a nine months long Liberation War, Bangabandhu strongly believed in the "powerful tides of self-determination"' and pledged that his country should always stand firmly "by the side of the oppressed people of the world." Applauding the great victories by the people of Algeria, Viet Nam and Guinea-Bissau, he boldly extended his support to the Arabs and the Palestinian people for their legitimate struggle for self-determination. Bangabandhu was a great believer in the Universal Declaration of HR. Citing the provisions of the Declaration, he stressed that "everyone everywhere should enjoy the economic, social and cultural rights indispensable for his dignity and the free development of his personality justice and equality." He also did not hesitate to tag the apartheid as a "crime against humanity" stating that it continues to "outrage 
the conscience of man." Noting the great advancement in the decolonization process, he applauded the 'heroic peoples' of Zimbabwe and Namibia, engaged in their struggle for national liberation. Thus, it is expected that Bangladesh's voting preferences at the UNGA would reflect the enduring ideals of advancing the global human rights situation, the Palestinian cause, decolonisation and democracy, as articulated by the father of the nation in his historic speech.

The HR, self-determination, decolonisation, democratisation and the Palestinian issues constitute around 50 per cent of the total resolutions that were put to vote at the Assembly between 2001-2017. The resolutions on Palestinian questions, and country-specific human rights situation dominates the HR category. These resolutions generally condemn the HR violation, discriminations and persecution by the member states and the non-state actors with in those countries. The resolutions on advancing decolonisation, democratisation and human rights norms call for enhancing the effectiveness of the principle of self-determination, periodic and genuine elections and the rights of the women and children. Figure 7 depicts Bangladesh's voting record on these resolutions. Bangladesh supported all resolutions on the Palestinian rights - a clear testimony of adhering to the ideals set out by Bangabandhu. The very first proposal co-sponsored by Bangladesh after her admission to the UN was that of including the question of Palestine in the agenda of the General Assembly (A/PV.2262, 9 October 1974, p.589). Bangladesh's opposition (i.e. no vote) regarding the advancement of HR resolutions relates to the provision of a moratorium on the use of the death penalty, an issue that the country is yet to reconcile like many other member states.

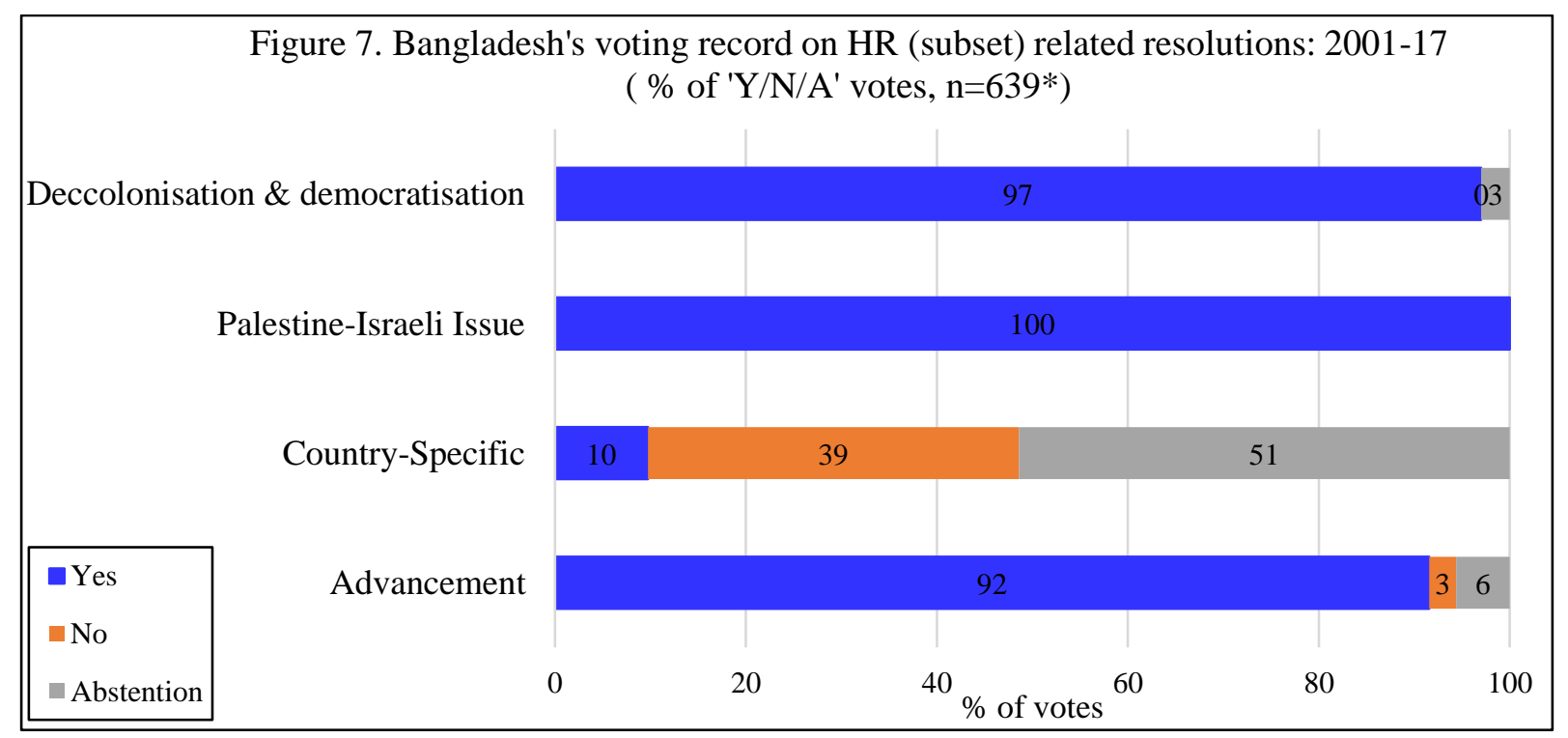

Source: Author's compilation from United Nations Department of Public Information (2001, 2002, 2003, 2004, 2005, 2006, 2007, 2008, 2009, 2010, 2011, 2012, 2013, 2014, 2015, 2016, 2017).

Note: * Data includes resolutions where Bangladesh was present and voting. 
However, Bangladesh's opposition (in 39\% resolutions) and abstention (in $51 \%$ resolutions) in case of the country-specific HR resolutions tends to suggest that the country is less aligned to the ideals of standing "by the side of the oppressed people of the world" as directed by Bangabandhu. This, however, needs to be viewed with two caveats. First, most freedom struggles in the '70s were against the colonial/occupying powers and the human rights abuse were by external powers or their sympathisers. In contrast, the contemporary HR abuses as recorded in the country-specific reports are often by the coercive apparatus of the state itself or the non-state actors within the state. Second, voting choice in resolutions on country-specific HR situations is politically sensitive as it risks being viewed as disrespecting the sovereignty and interfering into the internal affairs of a member state - particularly in case of a neighbour.

5.5 Regional and International Peace and foreign policy alignment. The speech captures Bangabandhu's profound wisdom and support for world peace. He viewed peace as the "deepest aspirations" of mankind, an "imperative for the survival" which must be based on "justice" to endure and sustain. He believed in the principles of peaceful coexistence and of friendship to all and malice to none- a core thinking that remains the hallmark of Bangladesh's foreign policy. Bangabandhu stressed that, only an environment of peace would enable Bangladesh (and other developing countries alike) to mobilize and concentrate national energies and resources in "combating the scourges of poverty, hunger, disease, illiteracy and unemployment.' His strong support for the non-aligned movement stemmed from his conviction that the movement is a powerful "forces of peace and progress". Accordingly, he wanted Bangladesh to avoid being the object in a political tug of war in the bipolar system. He envisioned a position for Bangladesh in which the country will stand along all nations of the world as worthy equals (Rahman, 2020). His vision is still relevant in South Asia where two key regional powers are vying for keeping the smaller states, including Bangladesh, under their sphere of influence.

From a regional perspective, Bangabandhu viewed the birth of Bangladesh as "materially contributing towards the creation of a structure of peace and stability" that could replace the past confrontation and strife with friendship and co-operation for the welfare of the region. He pledged that his country will continue to strive for good neighbourly relations with all, based on the principles of peaceful coexistence, respect for sovereignty and territorial integrity, and non-interference in one another's internal affairs. 
Figure 8. Bangladesh's voting record in Peace \& Security issues (\% of 'Y/N/A' votes, $\mathrm{n}=72 *$ )

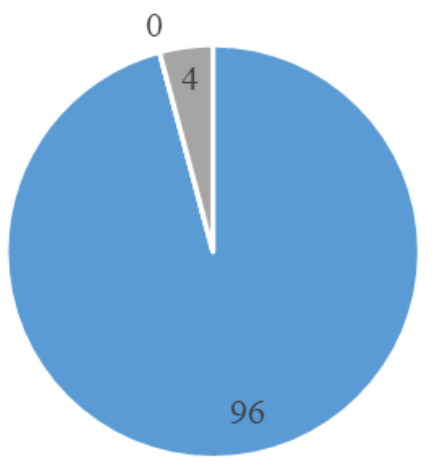

- Yes

- No

- Abstention

Source: Author's compilation from United Nations Department of Public Information (2001, 2002, 2003, 2004, 2005, 2006, 2007, 2008, 2009, 2010, 2011, 2012, 2013, 2014, 2015, 2016, 2017).

Note: * Data includes resolutions where Bangladesh was present and voting.

Pursuant to his philosophy of regional peace, Bangabandhu expressed Bangladesh's readiness to reconcile her relationship with Pakistan. He described the clemency granted to 195 Pakistani prisoners of war - accused of war crimes and crime against humanity, as an "investment towards the opening of a new chapter [with Pakistan] and towards the building of a future of peace and stability" in the subcontinent. As a humanist and pragmatists, he also mentioned the plight of the 63,000 stranded Pakistani families who reaffirmed their allegiance to Pakistan calling for their repatriation and a just division of the assets of former Pakistan.

Bangladesh's adherence to the father of the nation's pragmatism on regional and global peace can be traced in country's voting records in the peace and security related resolutions at the UNGA (see figure 6). These resolutions propose the establishment of the zone for peace and cooperation, adherence to the law of the sea, territorial integrity of the member states, use of science and technology for international security and disarmament, etc. Out of the 72 such resolutions in which Bangladesh was present and voting, the country supported 69 resolutions (96\%) with no opposition. The three abstention votes by Bangladesh relates to politically sensitive question of the unilateral declaration of independence of Kosovo (2008), territorial integrity of Ukraine (2013) and the withdrawal of foreign military forces from Moldova (2017).

\section{Conclusion}

Forty-six years ago, Bangabandhu, in his first speech at the Assembly outlined a set of enduring ideals for the new-born country. These ideals were pragmatic, universal and bold with a vision to position Bangladesh in the international stage as a peace-loving country and worthy equal. Bangabandhu's ideals included respecting universal human rights, rights for self-determination, peaceful co-existence, disarmament, non-proliferation, multilateralism and establishing a just international economic order. 
This paper investigated the question: to what extent has Bangladesh remained seized supporting the enduring ideals on key global issues enunciated by Bangabandhu in his speech at the United Nations? The paper used Bangladesh's voting records at the UNGA for the period 2001-17 to trace country's adherence to the ideals.

The paper has revealed that, except for the politically sensitive country-specific human rights issues, Bangladesh continued supporting Bangabandhu's ideals with remarkable consistency in all thematic categories (between 92-100\% 'yes' votes). Bangabandhu's emphasis on the primacy of the United Nations to build a peaceful and just world, non-alignment, peaceful co-existence, economic emancipation and global solidarity has become much more relevant in the Covid-19 era and the current geopolitical context of South Asia. The paper opens new avenues to conduct evidence-based research on the policy ideals and its practices using a novel methodology. The methodology can be expanded beyond the voting records, to analyse Bangladesh's compliance and actions on each thematic issue by employing other proxy variables, derived from the domestic and external context. Such scholarly studies could be a valuable tribute to the legacy of the father of the nation in his birth centenary year.

\section{References:}

Ahsan, Syed Badrul. (2020). Bangabandhu the statesman, The Financial express, 17 March 2020. Available at: https://thefinancialexpress.com.bd/mujib100/bangabandhu-the-statesman-1584424167 (Accessed 16 October 2020)

Ahmed, Forqan Uddin (2019). Remembering Bangabandhu's speech in United Nations, The Independent, 09 Octber 2019. Available at: http://www.theindependentbd.com/post/218740/ (accessed on 08 October)

Ahmed, Forqan Uddin (2020). Bangabandhu's Bengali speech at the UN; A memorable event in the world history. Available at: http://www.ourtimebd.com/beta/2020/10/01/bangabandhus-bengalispeech-at-the-un-a-memorable-event-in-the-world-history/

Alden, Robert. (1972). China's First U. N. Veto Bars Bangladesh, The New York Times, 26 August 1972. Available at: https://www.nytimes.com/1972/08/26/archives/chinas-first-un-veto-barsbangladesh-soviet-union-and-india-are.html/ (Accessed on 14 October 2020).

Alesina, A., \& Dollar, D. (2000). Who gives foreign aid to whom and why? Journal of Economic Growth, 5(1), 33-63. www.jstor.org/stable/40216022 (accessed on 12 October 2020).

A/PV.2233, 17 September 1974. United Nations General Assembly, Twenty-Ninth Session, Official Records, 2243rd Plenary Meeting, Agenda item 22: Admission of new Members to the United Nations. pp. 8-31.

A/PV.2243, 25 September 1974. United Nations General Assembly, Twenty-Ninth Session, Official Records, 2243rd Plenary Meeting. Address by Sheikh Mujibur Rahman, Prime Minister of Bangladesh, pp. 159-161. 
A/PV.2262, 9 October 1974. United Nations General Assembly, Twenty-Ninth Session, Official Records, $2262^{\text {nd }}$ Plenary Meeting. Speech by Mr. Hossain (Bangladesh), pp. 587-589.

Bailey, M. A., Strezhnev, A., \& Voeten, E. (2017). Estimating dynamic state preferences from United Nations voting data. Journal of Conflict Resolution, 61(2), 430-456. https://doi. org/10.1177/0022002715595700

Bangladesh Shangbad Shangtha (BSS). (2020) Bangabandhu's historic UNGA speech hailed in London, BSS News. Available at: http://www.bssnews.net/?p=460275 (accessed 12 October 2020).

Baxter, C. (1997). Bangladesh: From a Nation to a State, 1st Edition, Westview Press, Harper Collins.

Blair, H., W. (2001). Civil Society, Democratic Development and International Donors. In Jahan, R. (ed.) Bangladesh: Promise and Performance (pp. 181-217). Dhaka: Zed Books, The University Press Limited.

de Mesquita, B. (1975). Measuring systemic polarity. The Journal of Conflict Resolution, 19(2), 187216. www.jstor.org/stable/173415

Dreher, A., Nunnenkamp, P., \& Thiele, R. (2008). Does US aid buy UN General Assembly votes? A disaggregated analysis. Public Choice, 136(1/2), 139-164. www.jstor.org/stable/27698295

Dreher, A., \& Sturm, J. (2012). Do the IMF and the World Bank influence voting in the UN General Assembly? Public Choice, 151(1-2), 363-397. https://doi.org/10.1007/s11127-010-9750- 2

Gartzke, E. (2000). Preferences and the democratic peace. International Studies Quarterly, 44(2), 191-212. www.jstor.org/stable/3013995

Haas, P. M. (2018). Epistemic communities. In B. Badie, D. Berg-Schlosser, \& L. Morlino (Eds.), International encyclopedia of political science (pp. 788-791).

http://dx.doi.org/10.4135/9781412959636.n189

Hsieh, Hsiu-Fang \& Shannon, Sarah E. (2005). Three Approaches to Qualitative Content Analysis, Qualitative Health Research, Vol. 15 No. 9, November 2005, pp. 1277-1288.

DOI: $10.1177 / 1049732305276687$

Jahan, Rounaq (ed.) (2001) Bangladesh: Promise and Performance, Zed Books, The University Press Limited, Dhaka

Khan, Enayetullah (2020), Becoming Bangabandhu, UNB News, August 15, 2020. Available at: https://unb.com.bd/category/Opinion/becoming-bangabandhu/56015/ (accessed 04 October 2020).

Khan, M. Z. I. (2020a) Is voting patterns at the United Nations General Assembly (UNGA)a useful way to understand a country's policy inclinations: Bangladesh's voting records at the UNGA. SAGE Open. ISSN 2158-2440 doi: https://doi.org/10.1177/2158244020961117 (In Press)

Pevehouse, J. (2004). Interdependence Theory and the Measurement of International Conflict. The Journal of Politics, 66(1), 247-266. DOI:10.1046/j.1468-2508.2004. 00150.x

Rahman, AKM Atiqur. (2020). Bangabandhu in Algiers for Non-aligned Summit, The Daily Sun, 03 September 2020. Available at: https://www.daily-sun.com/post/503216/Bangabandhu-in-Algiers-forNonaligned-Summit/ (accessed on 12 October 2020). 
Stojanovic, Radoslav (1981), The Emergence of the Non-Aligned Movement: A View from Belgrade, Case Western Reserve Journal of International Law. Vil 13, issue 3 pp. 443-450. Available at: https://scholarlycommons.law.case.edu/jil/vol13/iss3/2

S/10558, 8 Mar 1972, Letter dated 8 March 1972 from the Permanente Representative of India to the United Nation addressed to the President of the Security Council containing a Letter Dated 14 Feb 1972 from the People's Republic of Bangladesh. pp.1-2.

S/10768, 21 August 1972. United Nations Security Council. China Draft Resolution. p. 1.

S/10774, 23 August 1972. United Nations Security Council, Official Document, S/10774, 23 August 1972, Note by the President of the Security Council (concerning admission to UN membership).

S/11316, 7 June 1974. United Nations Security Council. Report of The Security Council Committee on The Admission of New Members Concerning the Application of The People's Republic of Bangladesh For Admission to Membership in the United Nations.

S/PV-1660, 25 August 1972. United Nations Security Council, Official Records, Twenty Seventh Year, 1660th Meeting, New York, Admission of New Members. pp. 1-18.

S/PV- 1776, 10 June 1974. United Nations Security Council, Official Records, Twenty Seventh Year, 1660th Meeting, New York, Admission of New Members. pp. 1-18.

Smith, C. P. (2000). Content analysis and narrative analysis. In H. T. Reis \& C. M. Judd (Eds.), Handbook of research methods in social and personality psychology (p. 313-335). Cambridge University Press.

The Business Standard (2020). Bangabandhu's first UNGA speech Magna Carta for Bangladesh's multilateral diplomacy. The Business Standard, 26 September 2020. Available at:

https://tbsnews.net/bangladesh/bangabandhus-first-unga-speech-magna-carta-bangladeshsmultilateral-diplomacy-138019/ (accessed 10 October 2020).

United Nations Department of Public Information (UNDPI). (2001). The index to proceedings of the General Assembly, fifty-sixth session, 2001/02. https://library.un.org/index-proceedings/generalassembly

United Nations Department of Public Information (UNDPI). (2002). The index to proceedings of the General Assembly, fifty-seventh session, 2002/03. https://library.un.org/index-proceedings/ generalassembly

United Nations Department of Public Information (UNDPI). (2003). The index to proceedings of the General Assembly, fifty-eighth session, 2003/04. https://library.un.org/index-proceedings/ generalassembly

United Nations Department of Public Information (UNDPI). (2004). The index to proceedings of the General Assembly, fifty-ninth session, 2004/05. https://library.un.org/index-proceedings/generalassembly

United Nations Department of Public Information (UNDPI). (2005). The index to proceedings of the General Assembly, sixtieth session, 2005/6. https://library.un.org/index-proceedings/generalassembly 
United Nations Department of Public Information (UNDPI). (2006). The index to proceedings of the General Assembly, sixty-first session 2006/07. https://library.un.org/index-proceedings/generalassembly

United Nations Department of Public Information, (UNDPI). (2007). The index to proceedings of the General Assembly, sixty-second session 207/08. https://library.un.org/index-proceedings/generalassembly

United Nations Department of Public Information, (UNDPI). (2008). The index to proceedings of the General Assembly, sixty-third session 2008/09. https://library.un.org/index-proceedings/generalassembly

United Nations Department of Public Information, (UNDPI). (2009). The index to proceedings of the General Assembly, sixty-fourth session 2009/10. https://library.un.org/index-proceedings/ generalassembly

United Nations Department of Public Information (UNDPI). (2010). The index to proceedings of the General Assembly, sixty-fifth session 2010/11. https://library.un.org/index-proceedings/generalassembly

United Nations Department of Public Information (UNDPI). (2011). The index to proceedings of the General Assembly, sixty-sixth session 2011/12. https://library.un.org/index-proceedings/generalassembly

United Nations Department of Public Information (UNDPI). (2012). The index to proceedings of the General Assembly, sixty-seventh session 2012/13. https://library.un.org/index-proceedings/generalassembly

United Nations Department of Public Information (UNDPI). (2013). The index to proceedings of the General Assembly, sixty-eighth Khan 15 session 2013/14. https://library.un.org/indexproceedings/general-assembly

United Nations Department of Public Information (UNDPI). (2014). The index to proceedings of the General Assembly, sixty-ninth session 2014/15. https://library.un.org/indexproceedings/generalassembly

United Nations Department of Public Information (UNDPI). (2015). The index to proceedings of the General Assembly, seventieth session 2015/16. https://library.un.org/indexproceedings/generalassembly

United Nations Department of Public Information (UNDPI). (2016). The index to proceedings of the General Assembly, seventy-first session 2016/17. https://library.un.org/indexproceedings/generalassembly

United Nations Department of Public Information (UNDPI). (2017). The index to proceedings of the General Assembly, seventy-second session 2017/18. https://library.un.org/index-proceedings/generalassembly 
United Nations Security Council, (UNSC) (1972). Index to the Proceedings of Security Council, Twenty-Seventh Year- 1972, Dag Hammersmark Library, Bibliographical Series No. S.9. http://dag.un.org/bitstream/handle/11176/90460/S27.pdf?sequence=1\&isAllowed=y/

United Nations Security Council, (UNSC) (1974). The Repertoire of the Practice of the Security Council, Chapter VII: Practice Relative to Recommendations to the General Assembly Regarding the Membership in the United Nation (1972-1974). https://www.un.org/en/sc/repertoire/72-74/7274_07.pdf/

US State Department (2006) Unclassified US documents, Volume XI of the Foreign Relations of the United States on South Asia Crisis, 1971, Office of the Historian, US State Dept.

Zarif, Mannan Mashhur. (2020). Recognition, as equals: Tracing Bangabandhu's role in forming the principles of diplomacy and garnering international support for the newly-founded Bangladesh, The Daily Star, 17 March. 